\title{
COMPARATIVE ASSESSMENT OF SPRAY NOZZLES EFFICACY IN THE CONTROL OF FUSARIUM HEAD BLIGHT IN THE BARLEY CROPS USING DEVELOPED QUANTITATIVE PCR ASSAY
}

\author{
Oleh Hrytsev $\boldsymbol{I}^{\square}$ \\ olehhrytsev@gmail.com \\ Oleg Liudvinovskyi \\ Seedcare Institute ${ }^{3}$ \\ Julia Shevchenko \\ Diagnostic Centers CP Development\&Technical Support ${ }^{3}$ \\ Veronika Dzhagan \\ Department of Plant Biology \\ Larysa Skivka \\ ${ }^{1}$ Department of Microbiology and Immunology \\ ${ }^{2}$ Educational and Scientific Centre "Institute of Biology and Medicine" \\ Taras Shevchenko National University of Kyiv \\ 64/13, Volodymyrska Street, Kyiv, Ukraine, 01601 \\ ${ }^{3}$ LLC "Syngenta" 120/4 Kozatska str., Kyiv, Ukraine, 03680
}

$\triangle$ Corresponding author

\begin{abstract}
Fusarium species infect cereal spikes during anthesis and cause Fusarium head blight (FHB), a destructive disease of cereal crops with worldwide economic relevance. The necessity for these phytopathogenic fungi effective control becomes increasingly important for the production of both cultivated plants and those plants seeds. Fungicide application is a key methodology for controlling the disease development and mycotoxin contamination in cereals. Polymerase chain reaction (PCR) is currently the most commonly admitted DNA-based technology for specific, rapid and precise Fusarium detection. We have developed and patented the method for detection and quantitative determination of phytopathogenic fungi $F$. avenaceum and F. graminearum in plant seeds using Real-Time PCR with a pair of primers, designed to amplify sequences of the internal transcribed spacer at the ribosomal RNA gene cluster of those phytopathogenic fungi. This study was aimed to perform a comparative assessment of the efficacy of different spray nozzles for antifungal treatment to control $F$. avenaceum and $F$. graminearum infection of barley grains using a developed qPCR diagnostic system. A single application of a fungicide (active ingredient's content: $250 \mathrm{~g} / 1$ propiconazole, $80 \mathrm{~g} / 1$ cyproconazole) at BBCH 65 (middle of flowering) was carried out. For this purpose, four spray nozzles with different technical characteristics were used: Flat Fan 030, Amistar 030, Defy 3D 030 and Vegetable 060 (Pentair, USA). DNA-based fungi detection and identification was performed using conventional PCR and developed qPCR. The level of mycotoxins in barley grain was determined using enzyme-linked immunosorbent assay (ELISA). Grain count in the ear of barley and thousand seed weight (TSW) were also examined.

A single application of the fungicide inhibited the development of FHB and is accompanied by the slight increase of TSW values in treated plants. It was found, that the most effective fungicide was against $F$. avenaceum and $F$. graminearum. The inhibitory effect depended on sprayer type. According to qPCR results, the best performance was achieved when using Amistar 030 and Flat Fan (FF) 030 sprayers. The average concentration of deoxynivalenol (DON) content in all barley grain samples were up to 4 times higher than the permissible level. Overall, because of the high contamination levels, found in tested samples, it is possible to state that a single application of the fungicide at the flowering phase was not able to effectively reduce DON contamination in barley samples.
\end{abstract}


The developed test-system for qPCR provides new important information in the study of the effectiveness of fungicides and development of strategies to control FHB in cereals, not achievable with conventional PCR.

Keywords: Fusarium head blight, quantitative PCR, F. avenaceum, F. graminearum, mycotoxins.

DOI: $10.21303 / 2504-5695.2021 .001873$

\section{Introduction}

Fusarium head blight (FHB) is a devastating disease, affecting small cereals including wheat (Triticum aestivum L.) and barley (Hordeum vulgare L.) worldwide [1]. The disease is caused by a complex of 21 Fusarium species, including Fusarium avenaceum (Fr.) Sacc., Fusarium culmorum (W. G. Sm.) Sacc., Fusarium graminearum Schwabe (teleomorph stage: Gibberella zeae (Schwein.) Petch), F. poae (Peck) Wollenw., and F. sporotrichioides Sherb. [2, 3]. The above-mentioned phytopathogenic fungi affect kernel development, reducing yield and deteriorating grain grade. FHB causative agents also contaminate grain with a fungal toxins (mycotoxins), produced in infected seeds $[4,5]$. The ability to produce mycotoxins varies between species and also between strains of the same species. Mycotoxin biosynthesis by these fungi depends on various environmental conditions, such as temperature, humidity, $\mathrm{pH}$ etc. [6, 7]. It should also be noted, that the consumption of agricultural products, affected by fusariosis, can lead to alimentary mycotoxicosis in human and animals, such as fusariograminearotoxicosis and fusarionivaletoxicosis. These diseases are severe forms of food intoxication and are caused by mycotoxins, produced by F. graminearum and F. avenaceum [8]. Considering the fact of ant association of acute mycotoxicosis with serious and sometimes fatal diseases, the strict control of mycotoxin contamination is necessary to ensure food quality. The Scientific Committee for Food (SFC) of the European Commission has recently established a TDI (Tolerable Daily Intake) of $1 \mu \mathrm{g} / \mathrm{kg}$ bodyweight/day for mycotoxins in humans. In addition, the Commission of the European Community has established the maximum limits for Fusarium toxins (deoxynivalenol (DON), zearalenone (ZEA), and fumonisins (FUM) B1 and B2) in cereals and cereal-based products [9-11]. High effort was put into the development of strategies to control FHB in cereals [12, 13]. The total control of FHB by single protection measures fail. An integrated multifactorial approach that starts in the field before planting and goes on throughout the whole food chain is needed [14]. One of the important components of this complex strategy is the use of fungicides. Triazole fungicides, such as tebuconazole, propiconazole and metconazole, are currently the most effective chemical agents to reduce FHB severity and DON contents in cereals [15]. However, fungicide treatments cannot completely protect plants against infestation with Fusarium or mycotoxin contamination. Treatment efficacy highly depends on the active ingredient, the correct modes of operation and regulation of spraying speeds, the selection of optimal types and calibers of spray nozzles and even more on the timing of application. Only the application at a narrow time window of flowering may provide satisfactory results $[16,17]$. In addition, early, rapid, and specific identification of Fusarium infection is essential for effective plant disease management and control. It necessitates developing sensitive and specific diagnostic tools, capable to track Fusarium species rapidly [18]. However, conventional methods of fungal identification in cereal crops are time consuming and often inaccurate. These methods are especially complex for the Fusarium detection, since the genus is diverse, presents intraspecific variability, and conflicting taxonomy [19]. Polymerase chain reaction (PCR) is currently the most commonly admitted DNA-based technology for specific, rapid and precise Fusarium detection. Real-time quantitative PCR (qPCR) is a fast and high-throughput method that has opened new opportunities for quantitative detection of phytopathogenic fungi, investigation of plant pathogen interactions, fungal biology and epidemiology [20]. This diagnostic tool allows the detection and quantification of DNA targets by monitoring PCR product accumulation during the thermal cycling as indicated by increased fluorescence. Real-time PCR enables simpler and more rapid analysis of data and has higher sensitivity and a wider dynamic range compared to end-point PCR [21]. We have developed and patented the method for detection and quantitative determination of phytopathogenic fungi $F$. avenaceum and $F$. graminearum in plant seeds using Real-Time PCR with a pair of primers, designed to amplify sequences of the internal transcribed spacer at the ribosomal RNA gene cluster of those phytopathogenic fungi [22]. 
The aim of this study was to perform a comparative assessment of the efficacy of different spray nozzles for antifungal treatment to control $F$. avenaceum and $F$. graminearum infection of barley grains using a developed qPCR diagnostic system.

\section{Materials and Methods}

\section{1. Field experiments}

The study was conducted between April and June 2017 on the basis of Syngenta research station, Agronomichne village of Vinnytsia region, Ukraine (49 $\left.11^{\prime} 25.6^{\prime \prime} \mathrm{N} 28^{\circ} 20^{\prime} 42.8^{\prime \prime} \mathrm{E}\right)$. The experiment was carried out on spring barley of Armaks variety, sown on a total area of $3,000 \mathrm{~m}^{2}$ on April 2, 2017. This area was divided into 5 plots of $12 \times 50 \mathrm{~m}$, and the scheme of the experiment included the following variants (Table 1).

Table 1

Overview of the tested spray application techniques

\begin{tabular}{|c|c|c|c|c|c|}
\hline \multirow[b]{2}{*}{$\begin{array}{c}\text { Treatment character- } \\
\text { istics }\end{array}$} & \multirow[b]{2}{*}{ Control } & \multicolumn{4}{|c|}{ Nozzle type } \\
\hline & & $\begin{array}{c}\text { Flat Fan 030 } \\
\text { (Pentair, USA) }\end{array}$ & $\begin{array}{c}\text { Amistar 030 } \\
\text { (Pentair, USA) }\end{array}$ & $\begin{array}{c}\text { Defy 3D 030 } \\
\text { (Pentair, USA) }\end{array}$ & $\begin{array}{l}\text { Vegetable 060 } \\
\text { (Pentair, USA) }\end{array}$ \\
\hline Antifungal preparation & Untreated & $\begin{array}{c}\text { Alto Super (propi- } \\
\text { conazole } 250 \mathrm{~g} / \mathrm{L}, \\
\text { cyproconazole } 80 \mathrm{~g} / \mathrm{L} \text { ) }\end{array}$ & $\begin{array}{c}\text { Alto Super (propi- } \\
\text { conazole } 250 \mathrm{~g} / \mathrm{L}, \\
\text { cyproconazole } 80 \mathrm{~g} / \mathrm{L} \text { ) }\end{array}$ & $\begin{array}{c}\text { Alto Super (propi- } \\
\text { conazole } 250 \mathrm{~g} / \mathrm{L}, \\
\text { cyproconazole } 80 \mathrm{~g} / \mathrm{L} \text { ) }\end{array}$ & $\begin{array}{c}\text { Alto Super (propi- } \\
\text { conazole } 250 \mathrm{~g} / \mathrm{L}, \\
\text { cyproconazole } 80 \mathrm{~g} / \mathrm{L} \text { ) }\end{array}$ \\
\hline Speed km/h & - & 10 & 10 & 10 & 10 \\
\hline Water volume rate $\mathrm{L} / \mathrm{ha}$ & - & 130 & 130 & 130 & 280 \\
\hline Product rate $\mathrm{L} / \mathrm{ha}$ & - & 0.5 & 0.5 & 0.5 & 0.5 \\
\hline Spray angle & - & $110^{\circ}$ Fan Jet & $\begin{array}{c}110^{\circ} \text { Fan Jet and } \\
10^{\circ} \text { backwards facing }\end{array}$ & $\begin{array}{l}38^{\circ} \text { alternating for- } \\
\text { wards and backwards }\end{array}$ & vertical $\left(65^{\circ}\right.$ fan $)$ \\
\hline $\begin{array}{l}\text { Operating pressure } \\
\text { range }\end{array}$ & - & 1.0-6.0 Bar & 1.0-6.0 Bar & 1.0-4.0 Bar & 1.0-5.0 Bar \\
\hline
\end{tabular}

A single application of the fungicidal preparation ALTO SUPER 330 EC (active ingredient's content: $250 \mathrm{~g} / 1$ propiconazole, $80 \mathrm{~g} / 1$ cyproconazole) was carried out during the middle of flowering (BBCH-scale 65) on June 22, 2017 using different spray nozzles.

\section{2. Plant and seed materials}

Point sampling diagonally of research plots was used to obtain plant material for Fusarium detection and identification. The sampling was conducted just before fungicide application and 14 days after the treatment. Grains for the qPCR assay were harvested during barley dead ripening (BBCH-scale 93) [23]. Additionally, $50 \mathrm{~g}$ of grains were counted with a seed counter (Contador 2, Pfeuffer GmbH, Kitzingen, Germany) to determine the thousand seed weight (TSW) based on a grain moisture content of $12.5 \%$ [24].

\section{3. Fusarium DNA analysis}

Total genomic DNA was extracted using the Agrosorb NK kit (LLC Agrogen Novo, Ukraine). The quantity and purity of extracted DNA were measured using a spectrophotometer NanoDrop ND1000 (Thermo Fisher Scientific, USA). DNA purity was estimated from the A260/A280 ratio, and DNA concentration was calculated by measuring the absorbance at $260 \mathrm{~nm}$. The molecular identification of the species composition of fungi of Fusarium genus in the studied samples of spring barley was carried out using a set of reagents for PCR-amplification of DNA phytopathogens by electrophoresis, according to the manufacturer's instructions (LLC AgroDiagnostica, Russia).

The real-time PCR was carried out on a CFX96 Touch ${ }^{\mathrm{TM}}$ Real-Time PCR Detection System «CFX 96 Touch» (Bio-Rad Laboratories Ltd., USA) under thermal cycling parameters as follows: initial denaturation at $95^{\circ} \mathrm{C}$ for $10 \mathrm{~min}$; then, 35 cycles of denaturation at $95{ }^{\circ} \mathrm{C}$ for $5 \mathrm{~s}$, primer annealing at $60{ }^{\circ} \mathrm{C}$ for $30 \mathrm{~s}$. The reaction was conducted in a $20-\mu 1$ reaction mixture consisting of $10 \mu$ l Maxima Probe qPCR Master Mix 2x (Fermentas. Thermo Fisher Scientific Inc, Vilnius, 
Lithuania), $1 \mu \mathrm{l}$ of forward and reverse primer $(10 \mu \mathrm{M}), 0.5 \mu \mathrm{l}$ of probe $(10 \mu \mathrm{M}), 2 \mu 1$ of template DNA or pDNA, and sterile bi-distilled water up to a final volume of $20 \mu \mathrm{l}$.

To generate the standard curve, 10-fold dilutions of plasmid DNA, containing cloned DNA fragments of phytopathogenic fungi $F$. avenaceum and $F$. graminearum (ranging from 5 to 0.00005 attomol $/ \mu \mathrm{l}$ ), were subjected to qPCR under the same conditions, described above. The standard curve is a plot of the Ct versus log DNA concentration.

Sequences of specific primers and probes, used in the studies, are presented in Table 2. The internal control signal detection was performed using the fluorescent HEX (6-carboxy-4,7,2',4',5',7'-hexachlorofluorescein) label, while the detection of the signal for phytopathogenic fungi $F$. avenaceum and $F$. graminearum DNA sequence amplification was performed using the FAM (6-Carboxyfluorescein) fluorescent label. The amplification of internal exogenous control took place regardless of the presence of the DNA of phytopathogenic fungi, which indicates that there are no PCR reaction inhibitors in the DNA samples, and that the PCR reaction itself passes without interference. The results were automatically calculated using software Bio-Rad CFX Manager 3.1 (Bio-Rad Laboratories Ltd., USA).

Table 2

Primers and probes, used in the study

\begin{tabular}{ccc}
\hline Pathogen & Oligo name & Sequence (5'-3') \\
\hline \multirow{2}{*}{. avenaceum } & F_aven_tricin_S & GCCTGTTCGAGCGTCATTTC \\
& F_aven_AS & GCACCGCCAGAAGGCAG \\
F. graminearum & F_aven_tricin_probe & FAM - CCGATCCCCAACACCAAACCCG - BHQ1 \\
& F_gram_S & GAGCGTCATTTCAACCCTCAA \\
& F_gram_AS & GCTATGGAAGCTCGACGTGAC \\
Internal control & F_gram_probe & FAM - CAATGTATTTGGGGAGTGCAGCAGGAC - BHQ1 \\
& Int_ctrl_S & AGAATTACACGGCGATCTTTCC \\
& Int_ctrl_A & GACGAAGTACCGAAAGGTCTTACC
\end{tabular}

\section{4. Mycotoxin analysis}

The DON, T-2 mycotoxin, ZEA, FUM and aflatoxin (AF) content was determined using the enzyme-linked immunosorbent assay (ELISA) kit according to the manufacturer's instructions (RIDASCREEN ${ }^{2}$, R-Biopharm AG, Darmstadt, Germany). Readings were performed at $450 \mathrm{~nm}$ in the SunRise ELISA plate reader (Tecan Austria GmbH, Salzburg, Austria). All experiments were repeated three times and the measurements and calculations were conducted with Tecan Magellan 7.1 software (Tecan Trading AG, Switzerland).

\section{5. Data analysis}

All experiments were performed in triplicate. The statistical analysis of experimental data was conducted by the method of analysis of variance using computer software Excel and Statistica -10 [25]. The results are presented as mean \pm standard deviation, and values of $p<0.05$ were considered statistically significant.

\section{Results and discussion}

As a result of the qualitative PCR assay, totally five species of fungi of the Fusarium genus were found and identified in the plant materials of spring barley from 5 plots where different spray nozzles were placed prior to the fungicide application: $F$. avenaceum, F. culmorum, F. graminearum, F. poae and F. sporotrichioides (Table 3). It is necessary to point that $F$. culmorum DNA was revealed initially only on one plot.

The lack of F. culmorum DNA in the plant material from the rest of plots can be accounted for several factors:

1) the low total pathogen load; 
2) the delayed growth of this Fusarium specie due to the growth inhibitory effect, exerted by fungi of another species of the same genus, since such interspecies interactions are widely described [26].

Table 3

Species composition of fungi of Fusarium genus in the plant and grain material

\begin{tabular}{|c|c|c|c|c|c|}
\hline Nozzles type & Fusarium graminearum & Fusarium culmorun & Fusarium sporotrichioides & Fusarium poae & Fusarium avenaceum \\
\hline \multicolumn{6}{|c|}{ Before antifungal preparation application ${ }^{a}$} \\
\hline $\mathrm{WA}^{*}$ & + & - & + & + & + \\
\hline FF 030 & + & - & + & + & + \\
\hline Amistar 030 & + & + & + & + & + \\
\hline Defy 3D 030 & + & - & + & + & + \\
\hline Vegetable 060 & + & - & + & + & + \\
\hline \multicolumn{6}{|c|}{ 14-day after antifungal preparation application ${ }^{b}$} \\
\hline WA & + & + & + & + & + \\
\hline FF 030 & - & + & - & + & - \\
\hline Amistar 030 & - & - & - & + & - \\
\hline Defy 3D 030 & - & + & + & + & - \\
\hline Vegetable 060 & - & + & + & + & - \\
\hline \multicolumn{6}{|c|}{ Grain $^{c}$} \\
\hline WA & + & - & + & + & + \\
\hline FF 030 & + & - & - & + & - \\
\hline Amistar 030 & + & - & + & + & - \\
\hline Defy 3D 030 & + & - & + & + & - \\
\hline Vegetable 060 & + & - & + & + & - \\
\hline
\end{tabular}

Notes: * -WA - Without Applications, «-»-negative results; «+»-positive results; ${ }^{a}$ - before fungicide application; ${ }^{b}-14-$ days after the treatment; ${ }^{c}-$ harvested grain

The antifungal preparation, used in the study, was most effective for controlling two Fusarium species: F. graminearum and $F$. avenaceum (Table 3). The use of different spray nozzles for single application of the antifungal preparation resulted in different treatment efficacy. The highest treatment efficacy was registered on the plot with Amistar 030 - DNA of only one fungus was detected in the barley plant material 14 days after the processing with the antifungal $-F$. poae. It is necessary to note the inefficacy of the used antifungal for controlling this Fusarium species regardless of nozzle type. This inefficiency has been attributed to various factors including improper timing of application and poor fungicide efficacy against different Fusarium species [27]. One can suggest that the highest efficacy of nozzle can be attributed to its ability to reduce a spray drift by up to $75 \%$. Quite effective was the use of FF 030: DNA from two out of five Fusarium species was revealed. Surprisingly, we found F. culmorum DNA in the plant material from 4 plots where this Fusarium specie was absent initially, 14 days after the antifungal application. One can suggest that the growth of this specie was stimulated by the inhibitory antifungal effect towards antagonistic species of the same genus (e. g. F. graminearum) [28].

The analysis of Fusarium DNA in the barley grain material long after the single antifungal application revealed the presence of $F$. graminearum and $F$. poae DNA in all samples, indicating the low efficiency of the used preparation for controlling these species (Table 3).

One of the major drawbacks of conventional PCR is its inability to differentiate the DNA from dead and viable cells. This is an important factor for assessing the effectiveness of fungicides and one of the challenges for DNA-based molecular methods improvement [29]. Recently, the most common PCR method became the real-time PCR registration (real-time PCR), because, unlike most other PCR formats, it allows not only to establish the presence of Fusarium family phytopathogenic fungi DNA, but also to determine their number. Thus, this method allows us to identify DNA sequences, specific to phytopathogenic fungi of Fusarium family, and thereby to establish their presence in the sample under study and determine the DNA concentration of those above-mentioned phytopathogenic fungi. 
According to our own data and reports of other scientific groups, F. graminearum and $F$. avenaceum are most widespread and most harmful causative agents of FHB in Ukraine [30, 31]. Therefore, our efforts were concentrated on the development of the quantitative detection method for these Fusarium species.

Using the developed detecting system, we carried out the quantitative determination of phytopathogenic fungi $F$. avenaceum and $F$. graminearum in the plant and seed materials. Fig. 1 shows the standard curves of the dependence of the number of real-time PCR cycles $(\mathrm{Cq})$ on the value of $F$. graminearum and $F$. avenaceum DNA quantity in the reference standard $(\log )$.
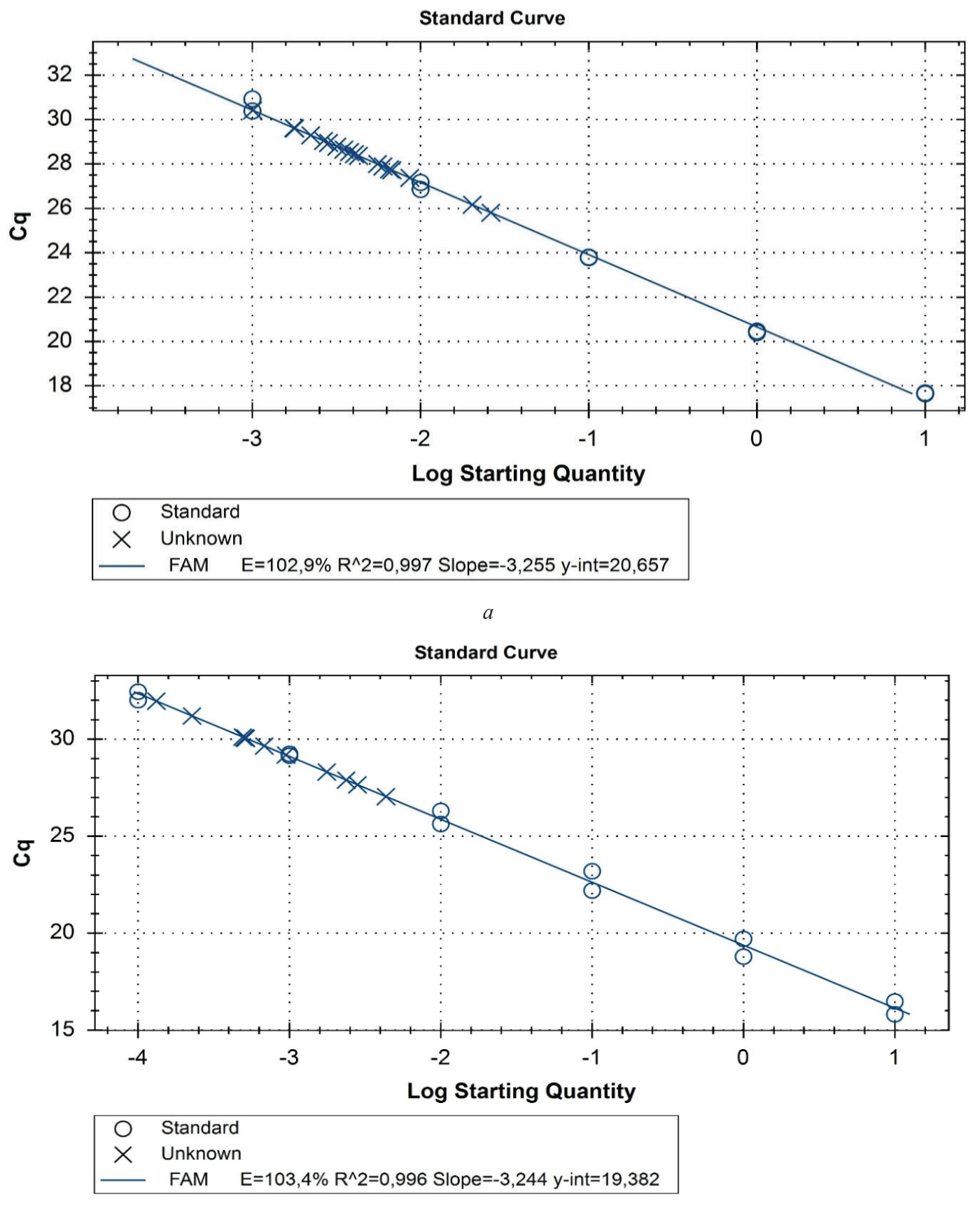

$b$

Fig. 1. The standard curves of the TaqMan qPCR for: $a$-Fusarium graminearum; $b-F$. avenaceum genomic DNA extracted from spring barley plants and seed materials against standard 
Fig. 1 presents standard dilutions of plasmid DNA, containing cloned DNA fragments of phytopathogenic fungi $F$. avenaceum and $F$. graminearum for quantitative determination from 5 to 0.00005 attomol $/ \mu 1$. This standard curve demonstrates the dependence of the real-time PCR cycles $(C q)$ number, required to obtain a fluorescence level, exceeding the threshold value on the logarithm value that corresponds to the phytopathogenic $F$. graminearum and $F$. avenaceum DNA quantity in the reference standard (log). Using this standard curve, the concentration of phytopathogenic fungi in the sample was determined based on the number of real-time PCR $(C q)$ cycles, after which the fluorescence intensity exceeded the limit value (Table 4).

\section{Table 4}

Quantification of $F$. graminearum and F. avenaceum with TaqMan qPCR. The result of the average values, shown in the Genome Equivalent (GE) copy number x $10^{5}$ per $100 \mathrm{mg}$ of plant or seed materials

\begin{tabular}{cccccc}
\hline \multirow{2}{*}{ Species } & \multicolumn{5}{c}{ Nozzles type } \\
\cline { 2 - 6 } & WA $^{*}$ & FF 030 & Amistar 030 & Defy 3D 030 & Vegetable 060 \\
\hline F. graminearum & 0.490 & 0.310 & 0.700 & 0.790 & 0.998 \\
F. avenaceum & 0.254 & 0.046 & 0.060 & 0.013 & 0.101 \\
\hline & \multicolumn{7}{c}{ Grain } & 0.294 & - \\
\hline F. graminearum & 3.251 & 0.089 & 0.176 & - & - \\
F. avenaceum & 0.440 & ND & - & &
\end{tabular}

It has been shown, that a single application of the fungicide differently inhibited the development of fusariosis depending on type sprayers. The effectiveness of $F$. graminearum control ranged from 50.7 to $74.9 \%$, while in the control plot the amount of DNA of the pathogen increased almost 6.5 times since the beginning of the experiment. The best performance was achieved when using Amistar 030 and Flat Fan (FF) 030 sprayers - 74.9\% and $68.1 \%$, respectively. The next in terms of control efficiency were Defy 3D $030-62.8 \%$ and Vegetable $060-50.7 \%$.

As for the control of F. avenaceum, in the plots where the fungicide was applicated, the effectiveness was $100 \%$ since the DNA of the phytopathogen was not detected. This may be due to a low pathogen load at the beginning of the experiment. According to qPCR results, the amount of $F$. avenaceum DNA at the control plot doubled.

In addition to the effectiveness of pathogen control, quantitative and qualitative indicators of the crop were evaluated. Namely, the level of accumulated mycotoxins, the thousand seed weight (TSW) and the number of grains in an ear.

It was found, that all samples were contaminated with a variety of mycotoxins. Since the mycotoxins content T-2, ZEN, FUM and AFs in the grain did not exceed the maximum permissible level in accordance with the commission regulation (EU) No. 1881/2006, special attention was paid to the level of DON content. Taking into account all the samples, the average concentration of DON was 4,600 $\mu \mathrm{g} / \mathrm{kg}$ (min-max: 1,400-16,500 $\mu \mathrm{g} / \mathrm{kg}$ ) and significantly exceeded the maximum permissible level for unprocessed cereals $(1,250 \mu \mathrm{g} / \mathrm{kg})$ (Table 5).

Table 5

Mycotoxin level in spring barley samples

\begin{tabular}{cccccc}
\hline \multirow{2}{*}{ Nozzles type } & \multicolumn{5}{c}{ Mycotoxins levels $(\boldsymbol{\mu g} / \mathbf{k g})$} \\
\cline { 2 - 6 } & DON $^{1}$ & T-2 & ZEN & FUM & AFs \\
\hline WA $^{2}$ & $14500 \pm 1927$ & $147.6 \pm 53$ & $0.3 \pm 0.09$ & $400 \pm 100.0$ & $0.7 \pm 0.03$ \\
FF 030 & $2200 \pm 475^{*}$ & $50.7 \pm 6.2$ & $0.4 \pm 0.18$ & $200 \pm 57.7$ & $0.4 \pm 0.33$ \\
Amistar 030 & $1600 \pm 206^{*}$ & $101.6 \pm 11.7$ & $0.1 \pm 0.09$ & $300 \pm 0.0$ & $0.1 \pm 0.08$ \\
Defy 3D 030 & $1700 \pm 53^{*}$ & $187.0 \pm 13.8$ & $0.4 \pm 0.12$ & $367.7 \pm 57.7$ & $0.1 \pm 0.06$ \\
Vegetable 060 & $2900 \pm 248^{*}$ & $103.5 \pm 27.2$ & $0.2 \pm 0.02$ & $333.3 \pm 57.7$ & $0.2 \pm 0.08$
\end{tabular}

Notes: DON, deoxynivalenol; T-2, T-2 toxin; ZEN, zearalenone; FUM, fumonisins; AFs, total aflatoxin (sum of B1, B2, G1 and G2). WA - Without Applications. All Data are expressed as Mean $\pm S D(n=3) . *-P \leq 0.05$ as compared to untreated samples 
It is known, that the main producers of DON are F. graminearum, F. culmorum and F. cerealis. In addition, annual climate and weather variability can contribute to changes in mycotoxin levels in field crops. Therefore, it was expected, that the highest concentration of DON (mean: 14,500 $\mu \mathrm{g} / \mathrm{kg}$ ) would be recorded on an untreated plot, as according to qPCR results, the amount of $F$. graminearum DNA was the highest and increased during the experiment. The lowest DON concentration among the variants of the experiment was found at the plots where the Amistar 030 sprayers (mean: $1600 \mu \mathrm{g} / \mathrm{kg}$ ) and Defy 3D 030 (mean: $1700 \mu \mathrm{g} / \mathrm{kg}$ ) were used. Next in terms of contamination were the plots where FF 030 (mean: $2200 \mu \mathrm{g} / \mathrm{kg}$ ) and Vegetable 060 (mean: $2900 \mu \mathrm{g} / \mathrm{kg}$ ) were used. Therefore, we can conclude that a single application of the fungicide significantly inhibits the development of phytopathogens, but not able to effectively reduce the level of mycotoxin contamination.

The number of grains in a barley ear is an important parameter for the yield evaluation. This parameter is determined both by the genetic characteristics of the variety and by the conditions of the environment where it is cultivated. In addition, this indicator is influenced by the presence or absence of mineral elements, such as nitrogen $(\mathrm{N})$, potassium $(\mathrm{K})$, copper $(\mathrm{Cu})$, zinc $(\mathrm{Zn})$, boron $(\mathrm{B})$ and manganese $(\mathrm{Mn})$ [32]. The number of grains in a barley ear from treated and untreated plant samples didn’t differ significantly (Table 6).

Table 6

The mean values of 1000 -seed weight and number grains per ear

\begin{tabular}{cccccc}
\hline & \multicolumn{3}{c}{ Nozzles type } \\
\hline Species & WA & FF 030 & Amistar 030 & Defy 3D 030 & Vegetable 060 \\
\hline $\begin{array}{c}1000 \text {-grain weight } \\
\text { (g) }\end{array}$ & $54.50 \pm 0.35$ & $59.64 \pm 0.34^{*}$ & $56.62 \pm 0.41^{*}$ & $55.60 \pm 0.11$ & $54.75 \pm 0.36$ \\
Grain/ear (pcs) & $17.67 \pm 0.58$ & $19.0 \pm 1.0$ & $17.67 \pm 0.58$ & $18.0 \pm 1.0$ & $17.33 \pm 0.58$
\end{tabular}

Notes: Data are expressed as Mean $\pm S D(n=3)$. Values of 1000-seed weight were determined at $12.5 \%$ moisture content. WA - Without Applications. ${ }^{*}-P \leq 0.05$ as compared to untreated samples

As for the thousand seed weight, the value of this parameter in the plots where the amount of DNA of F. graminearum, according to the results of qPCR, was the lowest $\left(0.089 \cdot 10^{5}\right.$ genomic equivalent), was the largest $-59.64 \mathrm{~g}$. The lowest values of the thousand seed weight were recorded in the control plot $(54.50 \mathrm{~g})$.

The findings of this study have to be seen in light of some limitations. The effect of a single application of antifungal preparation towards $F$. culmorum can't be estimated due to biological features of the infestation. In field conditions we observed plant infestation with the combination of phytopathogenic fungi. One can't exclude mutual influence causative agents concerning their sensitivity to antifungal preparations. Therefore, the effect of the used antifungal preparation on F. culmorum warrants future laboratory experiments and field trials. In addition, it was our first field trial, and developed protocol of the treatment should be modified and improved. The most opportune treatment timing (flowering or later stages of crop development) as well as changes in fungicide(s) type and dosage is likely to provide improved disease control.

\section{Conclusions}

1. A single application of the fungicide Alto Super inhibited the development of FHB, but didn't prevent grain contamination with DON. The most efficacy of the used fungicide was registered against $F$. avenaceum and $F$. graminearum.

2. The inhibitory effect of the fungicide depended on sprayer type. According to the qPCR results, the best performance was achieved when using Amistar 030. It suggests that double fan nozzles (which pulverize in two opposite directions) may improve the efficacy of the treatment with the fungicide.

3. The developed test-system for qPCR provides new important information in the study of the effectiveness of fungicides and development of strategies to control FHB in cereals, not achievable with conventional PCR. 
4. Due to internal exogenous control, the developed test-system can potentially be used for testing different cereal varieties (wheat, oats, corn, etc.) and their hybrids for resistance to Fusarium fungi, as well as for the evaluation of the efficiency of different antifungal agro-industrial strategies and technologies.

\section{Acknowledgement}

We would like to thank and certify our special acknowledgement to Syngenta in Ukraine for funding the research.

\section{Conflicts of Interest}

Authors declare no conflict of interest.

\section{References}

[1] Cowger, C., Arellano, C., Marshall, D., Fitzgerald, J. (2019). Managing Fusarium Head Blight in Winter Barley With Cultivar Resistance and Fungicide. Plant Disease, 103 (8), 1858-1864. doi: http://doi.org/10.1094/pdis-09-18-1582-re

[2] Osborne, L. E., Stein, J. M. (2007). Epidemiology of Fusarium head blight on small-grain cereals. International Journal of Food Microbiology, 119(1-2), 103-108. doi: http://doi.org/10.1016/j.ijfoodmicro.2007.07.032

[3] Ogrodowicz, P., Kuczyńska, A., Mikołajczak, K., Adamski, T., Surma, M., Krajewski, P. et. al. (2020). Mapping of quantitative trait loci for traits linked to fusarium head blight in barley. PLOS ONE, 15 (2), e0222375. doi: http://doi.org/10.1371/journal.pone.0222375

[4] Edwards, S. G., Godley, N. P. (2010). Reduction ofFusariumhead blight and deoxynivalenol in wheat with early fungicide applications of prothioconazole. Food Additives \& Contaminants: Part A, 27 (5), 629-635. doi: http://doi.org/10.1080/19440040903515942

[5] Khan, M. R., Fischer, S., Egan, D., Doohan, F. M. (2006). Biological Control of Fusarium Seedling Blight Disease of Wheat and Barley. Phytopathology®, 96 (4), 386-394. doi: http://doi.org/10.1094/phyto-96-0386

[6] Gagkaeva, T., Gavrilova, O., Orina, A., Lebedin, Y., Shanin, I., Petukhov, P., Eremin, S. (2019). Analysis of Toxigenic Fusarium Species Associated with Wheat Grain from Three Regions of Russia: Volga, Ural, and West Siberia. Toxins, 11 (5), 252. doi: http://doi.org/10.3390/toxins11050252

[7] Shi, H., Schwab, W., Yu, P. (2019). Natural Occurrence and Co-Contamination of Twelve Mycotoxins in Industry-Submitted Cool-Season Cereal Grains Grown under a Low Heat Unit Climate Condition. Toxins, 11 (3), 160. doi: http://doi.org/10.3390/ toxins 11030160

[8] Perincherry, L., Lalak-Kańczugowska, J., Stępień, Ł. (2019). Fusarium-Produced Mycotoxins in Plant-Pathogen Interactions. Toxins, 11 (11), 664. doi: http://doi.org/10.3390/toxins11110664

[9] Commission Regulation (EC) No 1881/2006 of 19 December 2006 setting maximum levels for certain contaminants in foodstuffs (2006). Official Journal of the European Union L, 364, 5-24. Available at: http://data.europa.eu/eli/reg/2006/1881/2020-10-14

[10] Daou, R., Joubrane, K., Maroun, R. G., Khabbaz, L. R. et. al. (2021). Mycotoxins: Factors influencing production and control strategies. AIMS Agriculture and Food, 6 (1), 416-447. doi: http://doi.org/10.3934/agrfood.2021025

[11] Ji, F., He, D., Olaniran, A. O., Mokoena, M. P., Xu, J., Shi, J. (2019). Occurrence, toxicity, production and detection of Fusarium mycotoxin: a review. Food Production, Processing and Nutrition, 1 (1). doi: http://doi.org/10.1186/s43014-019-0007-2

[12] Timmusk, S., Nevo, E., Ayele, F., Noe, S., Niinemets, Ü. (2020). Fighting Fusarium Pathogens in the Era of Climate Change: A Conceptual Approach. Pathogens, 9 (6), 419. doi: http://doi.org/10.3390/pathogens9060419

[13] Tateishi, H., Miyake, T., Mori, M., Sakuma, Y., Saishoji, T. (2014). Effect of application timing of metconazole on Fusarium head blight development and mycotoxin contamination in wheat and barley. Journal of Pesticide Science, 39 (1), 1-6. doi: http:// doi.org/10.1584/jpestics.d12-077

[14] McMullen, M., Bergstrom, G., De Wolf, E., Dill-Macky, R., Hershman, D., Shaner, G., Van Sanford, D. (2012). A Unified Effort to Fight an Enemy of Wheat and Barley: Fusarium Head Blight. Plant Disease, 96 (12), 1712-1728. doi: http://doi.org/ 10.1094/pdis-03-12-0291-fe

[15] Beyer, M., Pogoda, F., Pallez, M., Lazic, J., Hoffmann, L., Pasquali, M. (2014). Evidence for a reversible drought induced shift in the species composition of mycotoxin producing Fusarium head blight pathogens isolated from symptomatic wheat heads. International Journal of Food Microbiology, 182-183, 51-56. doi: http://doi.org/10.1016/j.ijfoodmicro.2014.05.002

[16] Paul, P. A., Salgado, J. D., Bergstrom, G., Bradley, C. A., Byamukama, E., Byrne, A. M. et. al. (2019). Integrated Effects of Genetic Resistance and Prothioconazole + Tebuconazole Application Timing on Fusarium Head Blight in Wheat. Plant Disease, 103 (2), 223-237. doi: http://doi.org/10.1094/pdis-04-18-0565-re

[17] World Health Organization (2019). Equipment for vector control specification guidelines. Available at: https://www.who.int/ publications/i/item/9789241513821 
[18] Jurado, M., Vázquez, C., Patiño, B., Teresa González-Jaén, M. (2005). PCR detection assays for the trichothecene-producing species Fusarium graminearum, Fusarium culmorum, Fusarium poae, Fusarium equiseti and Fusarium sporotrichioides. Systematic and Applied Microbiology, 28 (6), 562-568. doi: http://doi.org/10.1016/j.syapm.2005.02.003

[19] Piacentini, K., Rocha, L., Savi, G., Carnielli-Queiroz, L., De Carvalho Fontes, L., Correa, B. (2019). Assessment of Toxigenic Fusarium Species and Their Mycotoxins in Brewing Barley Grains. Toxins, 11 (1), 31. doi: http://doi.org/10.3390/toxins11010031

[20] Ioos, R., Fabre, B., Saurat, C., Fourrier, C., Frey, P., Marçais, B. (2010). Development, Comparison, and Validation of Real-Time and Conventional PCR Tools for the Detection of the Fungal Pathogens Causing Brown Spot and Red Band Needle Blights of Pine. Phytopathology®, 100 (1), 105-114. doi: http://doi.org/10.1094/phyto-100-1-0105

[21] Scarlett, K., Tesoriero, L., Daniel, R., Guest, D. (2013). Detection and quantification of Fusarium oxysporum f. sp. cucumerinum in environmental samples using a specific quantitative PCR assay. European Journal of Plant Pathology, 137 (2), $315-324$. doi: http://doi.org/10.1007/s10658-013-0244-1

[22] Hrytsev, O., Shevchenko, J., Shostak, L., Kuklin, A. (2021). Pat. No. 123612 UA. Method for detection and quantitative determination of phytopathogenic fungi F. avenaceum and F. graminearum in seeds or plants using Real-Time PCR and a pair of primers designed to amplify sequences of the internal transcribed spacer at the ribosomal RNA gene cluster of those phytopathogenic fungi. MPK: C12N15/00, C12Q1/686, C12Q1/6895. No. a201909278. declareted: 14.08.2019; published: 28.04.2021. Available at: https://sis.ukrpatent.org/uk/search/detail/1590808/

[23] Meier, U. (1997). Growth stages of mono- and dicotyledonous plants: BBCH-Monograph. Blackwell Wissenschafts-Verlag, 622.

[24] Chapter 10: Weight determination. (2017). International Rules for Seed Testing, 2017 (1), 1-8. doi: http://doi.org/10.15258/ istarules.2017.10

[25] Prysiazhniuk, O., Karazhbei, H., Leshchuk, N., Tsyba, S., Mazhuha, K., Brovkin, V. et. al. (2016) Statistical analysis of agronomic research data package Statistica 10: Guidelines. Nilan-Ltd.

[26] Kuzdraliński, A., Szczerba, H., Tofil, K., Filipiak, A., Garbarczyk, E., Dziadko, P. et. al. (2014). Early PCR-based detection of Fusarium culmorum, F. graminearum, F. sporotrichioides and F. poae on stem bases of winter wheat throughout Poland. European Journal of Plant Pathology, 140 (3), 491-502. doi: http://doi.org/10.1007/s10658-014-0483-9

[27] Masiello, M., Somma, S., Ghionna, V., Logrieco, A. F., Moretti, A. (2019). In Vitro and in Field Response of Different Fungicides against Aspergillus flavus and Fusarium Species Causing Ear Rot Disease of Maize. Toxins, 11 (1), 11. doi: http://doi.org/ 10.3390/toxins 11010011

[28] Cendoya, E., Nichea, M. J., Monge, M. del P., Zachetti, V. G. L., Chiacchiera, S. M., Ramirez, M. L. (2021). Effect of fungicides commonly used for Fusarium head blight management on growth and fumonisin production by Fusarium proliferatum. Revista Argentina de Microbiología, 53 (1), 64-74. doi: http://doi.org/10.1016/j.ram.2019.12.005

[29] Zeng, D., Chen, Z., Jiang, Y., Xue, F., Li, B. (2016). Advances and Challenges in Viability Detection of Foodborne Pathogens. Frontiers in Microbiology, 7. doi: http://doi.org/10.3389/fmicb.2016.01833

[30] Hrytsev, O., Zozulya, A., Vorobieva, N., Skivka, L. (2018). Monitoring of species composition of fungi of the genus Fusarium in seed materials of winter wheat on Ukrainian territory. Microbiology\&Biotechnology, 2 (42), 81-89. doi: http://doi.org/ $10.18524 / 2307-4663.2018 .2(42) .134443$

[31] Retman, S., Kyslykh, T. (2011). Fusarium head blight: analysis of changes in the pathogenic complex of pathogens. Quarantine and plant protection, 2, 1-3.

[32] Boorboori, M. R., Asli D. E., Tehrani M.M. (2012). Effect of micronutrient application by different methods on yield, morphological traits and grain protein percentage of barley (Hordeum vulgare L.) in greenhouse conditions. Revista Científica UDO Agricola, 12 (1), 127-134.

How to cite: Hrytsev, O., Liudvinovskyi, O., Shevchenko, J., Dzhagan, V., Skivka, L. (2021). Comparative assessment of spray nozzles efficacy in the control of fusarium head blight in the barley crops using developed quantitative PCR assay. EUREKA: Life Sciences, 4, 9-18. doi: https://doi.org/10.21303/2504-5695.2021.001873 